\title{
A new species of Glaphyropoma: the first subterranean copionodontine catfish and the first occurrence of opercular odontodes in the subfamily (Siluriformes: Trichomycteridae)
}

\author{
Maria Elina Bichuette ${ }^{1}$, Mario César Cardoso de Pinna ${ }^{2}$ and Eleonora Trajano ${ }^{3}$
}

\begin{abstract}
A new species of the rare copionodontine genus Glaphyropoma is described from subterranean waters in the Diamantina Plateau, Bahia State, central northeastern Brazil. This is the first troglomorphic species in the subfamily Copionodontinae. It is distinguished from all other copionodontines by the presence of opercular odontodes, and further distinguished from its only congener, G. rodriguesi, by the reduction of dark integumentary pigmentation. The new species shares the single synapomorphy previously proposed for Glaphyropoma, the marked narrowing of the first hypobranchial and indirect character evidence also supports its inclusion in the genus. The presence of opercular odontodes in the new species, in combination with a reviewed hypothesis of sister group relationship between Copionodontinae and Trichogeninae, indicate that the absence of opercular odontodes in previously-known copionodontines is secondary, rather than primitive.
\end{abstract}

Uma nova espécie do raro gênero de Copionodontinae Glaphyropoma é descrita de águas subterrâneas da Chapada Diamantina, estado da Bahia, região central do Nordeste Brasileiro. Esta é a primeira espécie troglomórfica na subfamília Copionodontinae. Distingue-se de todos os outros Copionodontinae pela presença de odontódeos operculares, e de seu único congênere, $G$. rodriguesi, também pela redução de pigmentação tegumentar. A nova espécie apresenta a única sinapomorfia previamente proposta para Glaphyropoma, um estreitamento acentuado do primeiro hipobranquial e evidência indireta de outros caracteres também suportam sua inclusão no gênero. A presença de odontódeos operculares na nova espécie, em combinação com uma hipótese revisada de grupo-irmão entre Copionodontinae e Trichogeninae, indica que a ausência de odontódeos operculares nos Copionodontinae previamente conhecidos é secundária e não primitiva.

Key words: Biodiversity, Cave fishes, Systematics, Neotropics, Taxonomy.

\section{Introduction}

Perhaps the most intriguing discovery in trichomycterid diversity in recent decades has been the subfamily Copionodontinae. The group was originally described to include the genus Copionodon de Pinna, 1992 with two species, and Glaphyropoma de Pinna, 1992 with one (de Pinna, 1992). A fourth species was subsequently described in the genus Copionodon (Campanario \& de Pinna, 2000) and a few additional ones await description. Copionodontines occur exclusively in the Chapada Diamantina, a vast and complex plateau composed of Proterozoic terrain extending along a more or less northsouth axis in the State of Bahia, northeastern Brazil. Much of the plateau is above $1000 \mathrm{~m}$ altitude, with several peaks reaching over $2000 \mathrm{~m}$. The Chapada Diamantina is drained by four different basins, rio São Francisco to the west, rio de Contas to the south, rio Paraguaçu to the east and north and rio Itapicuru to the north. So far, copionodontines have been found exclusively in drainages associated with the rio Paraguaçu.
However, much of the Chapada Diamantina is accessible only with difficulty and vast portions of it remain unsampled. It is possible that copionodontine catfishes will be found to occur also in suitable environments in headwaters of the other drainages in the plateau.

Copionodontines are remarkably primitive morphologically, and lack many of the synapomorphies that were previously used to diagnose the Trichomycteridae. They were originally described as sister group to all the rest of the family (de Pinna, 1992). Later (de Pinna, 1998), some shared synapomorphies were identified for copionodontines and the relict southeastern Brazilian Trichogenes longipinnis Britski \& Ortega. There is little doubt that the Copionodontinae forms a monophyletic group, diagnosed by several unambiguous synapomorphies, including a unique dentition composed of spatulate teeth not seen anywhere else in the Trichomycteridae. A few characters also support the genera Copionodon and Glaphyropoma as monophyletic subunits.

Copionodontines occupy the upper reaches of fast-flowing streams on rocky beds, often with tiny or no water flow in

${ }^{1}$ Departamento de Ecologia e Biologia Evolutiva, Universidade Federal de São Carlos, Rodovia Washington Luís, km 235, P.O. Box 676, 13565-905 São Carlos, SP, Brazil. bichuette@uol.com.br

${ }^{2}$ Museu de Zoologia da Universidade de São Paulo, Av. Nazaré, 481, 04263-000 São Paulo, SP, Brazil. pinna@ib.usp.br

${ }^{3}$ Departamento de Zoologia, Instituto de Biociências, Universidade de São Paulo. P.O. Box. 11461, 05422-970 São Paulo, SP, Brazil. etrajano@usp.br 
the dry season. Fish tend to concentrate on quiet deep pools, though some individuals lodge in narrow rock crevices in fast flowing sectors. Habitat preferences also vary according to species. Water in the upper reaches of the Chapada Diamantina is cool and usually black (tea-stained), but there are records of copionodontines in a few clear water streams as well. Usually they share their environment with few or no other fish species.

Glaphyropoma is the most enigmatic copionodontine. The type series of G. rodriguesi de Pinna, 1992 remains the largest collection of the genus yet available. That series was collected with rotenone, which is a sampling method no longer legal in Brazil. Since then, only two additional specimens have been secured, one of which from a distinct subdrainage in a locality rather distant from the type locality of G. rodriguesi. Those facts suggest that Glaphyropoma is widely distributed in the Diamantina plateau and probably not as rare in nature as might be suggested by its meager representation in collections. Their small eyes and more depressed body and head, when compared to species of Copionodon, indicate a more cryptic behavior and perhaps an increased ability to hide in deep narrow rock crevices difficult to reach with collecting gear.

In this paper, we report on the discovery of a new species of Copionodontinae which was found in cave streams in the eastern portion of the Diamantina plateau. The new species is herein described and included in the genus Glaphyropoma, based on its hypothesized position as the sister group to G. rodriguesi.

\section{Material and Methods}

Morphometric data were taken with digital calipers, following the methods used by de Pinna (1992). Osteological information was taken from one specimen cleared and counterstained (c\&s) for bone and cartilage according to the method of Taylor \& Van Dyke (1985). Osteological information from additional specimens, including vertebral counts, was taken from digital radiographs. Illustrations were prepared with the help of a camera lucida, with final artwork prepared against direct examination of the specimen. MZUSP, Museu de Zoologia, Universidade de São Paulo, São Paulo.

Comparative material examined. Copionodon pecten, MZUSP 42461, 10 (3 c\&s), paratypes; Copionodon orthiocarinatus
Campanario \& de Pinna, 2000, MZUSP 42463, holotype; MZUSP 42464, 2 (1 c\&s), paratypes; Glaphyropoma rodriguesi, MZUSP 42466, 14 (2 c\&s), paratypes.

\section{Glaphyropoma spinosum, new species Figs. 1-6}

Holotype. MZUSP 99742, 58.2 mm SL, Brazil, State of Bahia, Chapada Diamantina, Município de Andaraí, Povoado de Igatu, Gruna

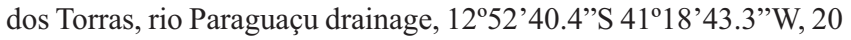
Jan 2006, M. E. Bichuette, F. D. Passos \& R. Borowsky.

Paratypes. MZUSP 99743, 4 (1 c\&s), 34.9-45.6 mm SL, same locality as the holotype, 2 Jan 2007, M. E. Bichuette, F. D. Passos \& T. L. C. Scatolini.

Diagnosis. Distinguished from all other copionodontine catfishes by the presence of opercular odontodes. Further distinguished from its only congener, G. rodriguesi, by the reduction of dark integumentary pigmentation.

Description. Morphometric data for holotype and paratypes presented in Table 1. For general aspect refer to Fig. 1. Body elongate, depressed in head and anterior trunk region, crosssection roughly circular from middle of trunk to origin of dorsal fin, gradually more compressed towards tail. Caudal peduncle region strongly compressed. Dorsal profile of trunk near dorsal fin nearly parallel to longitudinal axis of body, gently convex anteriorly and continuous with dorsal profile of head. Dorsal profile of body posterior to dorsal fin straight to base of caudal fin. Ventral profile of head straight, continuing in gently convex curve to pelvic-fin insertion. Ventral profile of body from origin of pelvic fin to origin of caudal peduncle nearly straight, slightly concave along caudal peduncle. Myotomes not evident through skin, except near caudal fin base.

Integument thick, especially on back and sides of trunk, forming folds on sides of trunk in large specimens, thinnest on abdominal region. Bases and proximal portions of all fins covered with thick layer of integument, most notably on dorsal and anal fins. Skin papillae small, most concentrated on ventral surface of head and barbels.

Head wide and depressed, wider than long in large specimens (holotype and larger paratype; Fig. 2), and slightly narrower in smaller specimens. Shape of head in large specimens

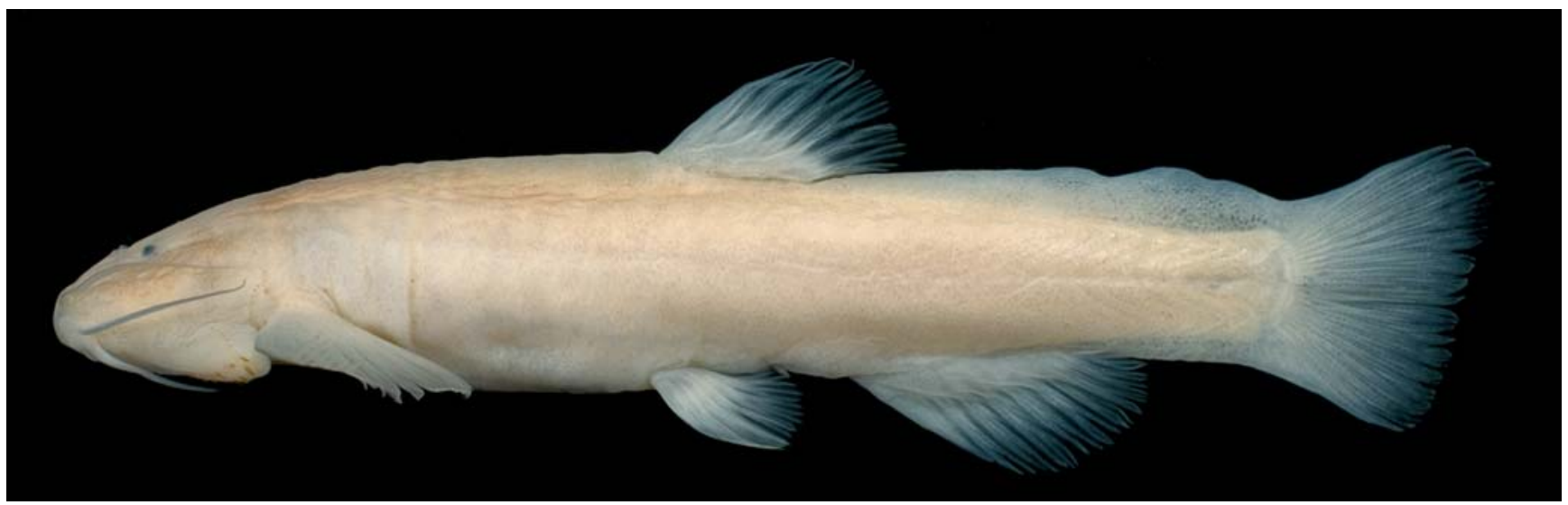

Fig. 1. Glaphyropoma spinosum, new species. Holotype, MZUSP 99742, 58.2 mm SL, Bahia, Brazil, Chapada Diamantina, Município de Andaraí, Povoado de Igatu, Gruna dos Torras, rio Paraguaçu drainage. Lateral view. 
nearly semicircular in dorsal view. Anterior part of lateral margin of head expanded over base of maxillary barbel. Eyes very small, without free orbital rim, almost entirely dorsal on head and partly sunk in integument. Lens visible through integument. Eyes located slightly closer to tip of snout than to dorsal margin of branchial membrane, and nearly equidistant between midline and lateral margin of head.

Anterior naris extended anterolaterally by tube of integument, continuous with nasal barbel. Posterior naris closer to eye than to anterior naris, partially closed by two thin flaps of skin not forming continuous tube. Posterior nares closer together than anterior ones.

Mouth inferior, located close to anterior margin of snout, not strongly flattened ventrally (Fig. 3). Upper and lower lips narrow in ventral view, the latter not divided in lateral halves by ridge. Posterior limit of lower lip not well-defined, mostly continuous with mental region (Fig. 3). Angle of mouth with fleshy outgrowth just posterior to rictal barbel.

Most teeth in first row of premaxilla and dentary distally expanded and flat, symmetrically spatulate and not overlapping distally. Fourteen or fifteen teeth in first dentary row extending nearly entire length of bone to base of coronoid process. Teeth progressively smaller and less spatulate laterally, with 3 or 4 lateralmost teeth conical. Eleven or twelve teeth on outer row of premaxilla, similar in morphology to those on dentary and with 2 or 3 lateralmost ones conical. Distal portions of all teeth darkly-pigmented, more markedly so in spatulate ones. Second row of premaxillary and dentary teeth much less markedly spatulate than those in first row. Teeth of subsequent rows mostly conical, with a few slightly compressed at tip.

Branchial membranes thick, narrowly attached to isthmus anteriorly. Branchiostegal rays seven, not visible through skin in alcohol-preserved specimens.

Barbels long and slender, with visible internal cores, their length variable bilaterally and among specimens. Maxillary barbel reaching between middle and posterior margin of pectoral-fin base. Rictal barbel extending to middle of interopercular patch of odontodes. Nasal barbel reaching anterior margin of pectoral-fin base or its middle.

Interopercle with two rows of odontodes (Fig. 3), ventral (large) and dorsoposterior (small). Ventral patch of odontodes extending along posterior part of ventral margin of head, its anterior point separated from lower lip by distance roughly equivalent to mouth width. Posterior point of patch nearly reaching vertical through anterior margin of pectoral-fin base. Odontodes light brown on distal half, disposed in two irregular rows, those on inner (posterior) row larger. Odontodes increasing in size posteriorly, with largest ones located at posterior tip of inner row. Largest odontodes slightly flattened and expanded distally, round at tip and bent at midlength. Eight or nine odontodes in inner row of ventral patch. Dorsal patch much smaller than ventral one, located laterally on posterior portion of head and with four to six small conical odontodes disposed in single curved row. Odontodes of dorsal patch almost entirelly hidden in integument, visible externally by their individual skin clefts and darkly-pigmented tips. Opercle with small odontode patch located slightly anterior to vertical through origin of pectoral fin. Five or six small conical opercu- lar odontodes arranged in single row, with their axes oriented posteroventrally (Fig. 4). Opercular patch of odontodes underlain by small fold of integument and mostly hidden in skin, with only tips of individual odontodes exposed.

Lateral-line canal externally visible, extending midlaterally in four to seven interrupted segments from head to, at most, vertical through origin of pelvic fins. Lateral-line ossicles absent. Infraorbital branch of latero-sensory canal system complete, detectable externally by its three pores or in outline in emaciated specimens. Infraorbital canal leaving neurocranium exclusively through sphenotic. Infraorbital bones absent except for first one (lacrimal).

Pectoral fin elongated, roundish-triangular in shape when expanded, its insertion slightly anterior to dorsal limit of branchial membrane (Figs. 1,2). Muscular base of pectoral fin broad. Pectoral-fin rays $i+10$, with first (unbranched) ray strongly curved posteriorly (more so along proximal half) and approximately same length as remaining ones, not prolonged as filament.

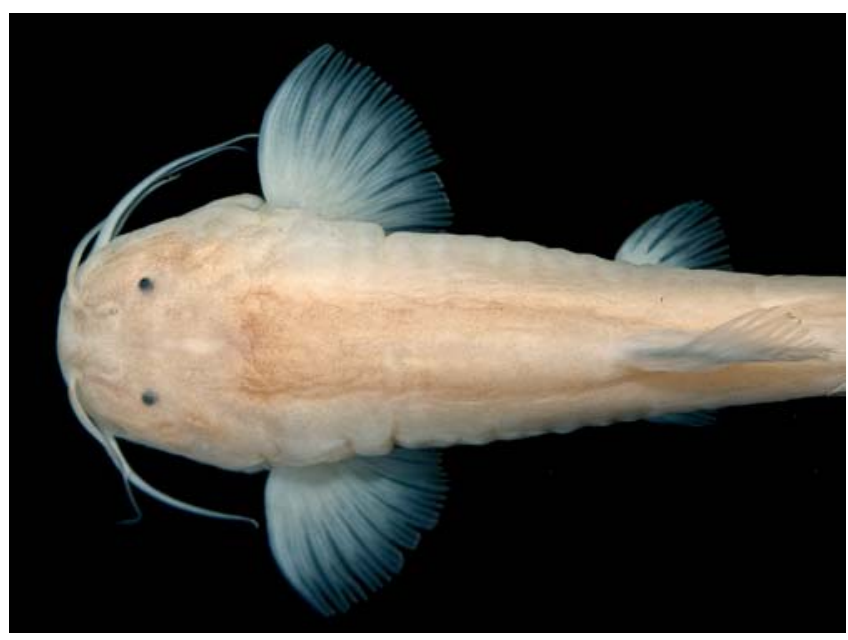

Fig. 2. Glaphyropoma spinosum, new species. Holotype, MZUSP 99742, $58.2 \mathrm{~mm}$ SL. Dorsal view of head and trunk.

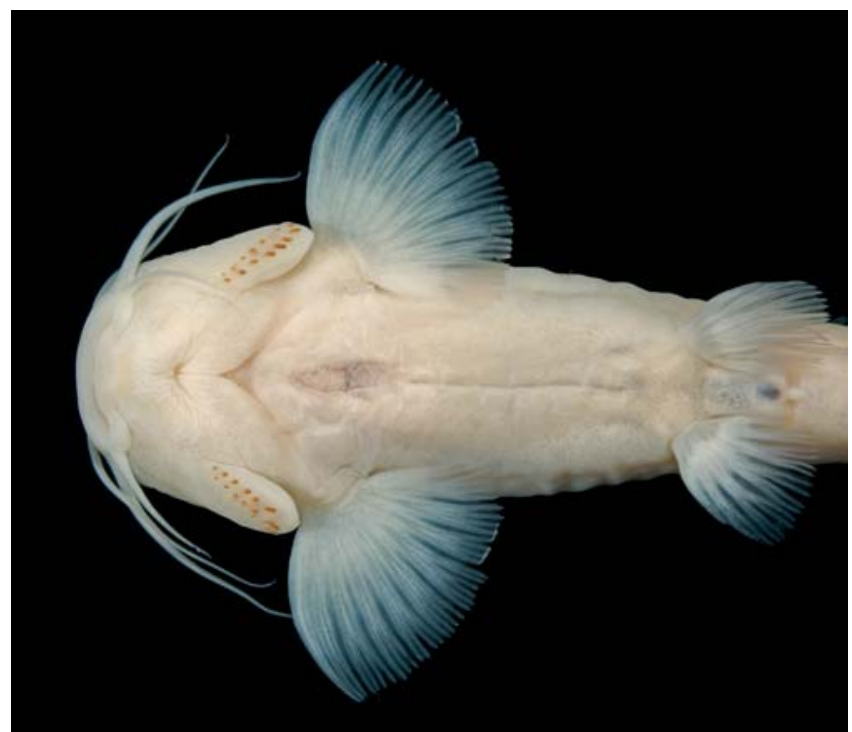

Fig. 3. Glaphyropoma spinosum, new species. Holotype, MZUSP 99742, 58.2 mm SL. Ventral view of head and abdomen. 
Pelvic fin medium size with round distal margin. Origin of pelvic fin closer to tip of snout than to base of caudal fin, at vertical through origin of dorsal fin. Pelvic-fin rays $i+5$ (one paratype) or i+6 (remaining specimens), with first ray (unbranched) curved and shorter than all succeeding rays but for last one. Pelvic splint absent.

Dorsal-fin origin equidistant between base of caudal fin and tip of snout, with ii+7 (most specimens) or ii +8 (c\&s paratype) rays. Anal fin larger than dorsal, with broadly convex profile, its origin slightly closer to medial point of branchial membrane than to posterior margin of caudal fin. Anal-fin rays $\mathrm{iii}+9, \mathrm{ii}+9$ or ii +10 (holotype), plus two anterior procurrent rays.

Caudal fin shape variable, ranging from truncate, to truncate with round edges, emarginate or slightly concave. Posterior profile oblique, resulting in upper lobe longer than lower one. Principal caudal-fin rays $i+7$ and $8+i$, procurrent rays weakly developed, five dorsally and six or seven ventrally.

Adipose fin large and conspicuous, extending for nearly entire region between dorsal and caudal fins. Anterior origin of adipose fin gently rising from immediately posterior to dorsal fin, reaching greatest depth on its posterior half and posteriorly continuous with caudal fin. Limit between two fins not well-defined, located in region with concave profile. Entire adipose fin covered with nearly continuous layer of large adipose tissue.

Vertebrae 30 or 31 , first dorsal-fin pterygiophore immediately posterior to neural spine of vertebra 7; first anal-fin pterygiophore immediately posterior to hemal spine of vertebra 13. Nine pleural ribs.

Pigmentation in alcohol. Dark coloration faint, most specimens white in superficial aspect, although none lacking dark integumentary pigment altogether. Dark chromatophores mostly concentrated on dorsal part of head and dorsum, uniformly scattered, not forming definite pattern. Densest concentration along middle of dorsum, forming broad dark middorsal band in some specimens, abruptly fainter anteriorly at edge of neurocranium and gradually fainter posteriorly, disappearing entirely posterior to dorsal fin (Fig. 2). Dorsal sur-

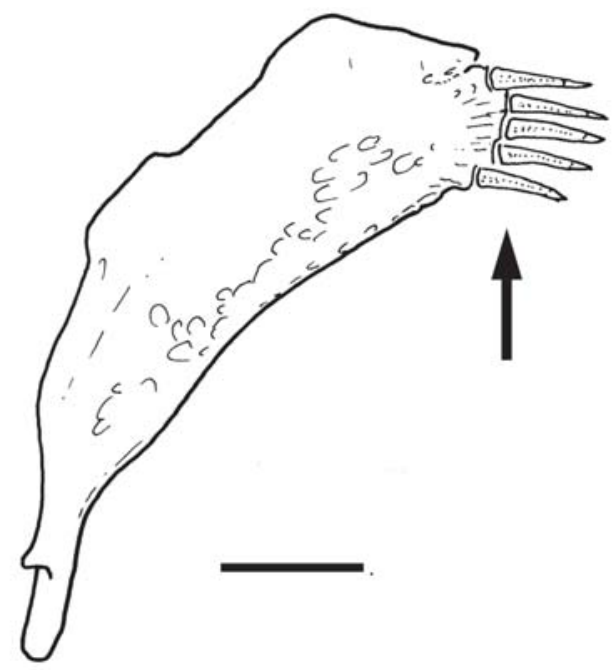

Fig. 4. Opercle of Glaphyropoma spinosum, new species. Lateral view of left side. Arrow indicates opercular patch of odontodes. MZUSP 99743. Scale bar $=1 \mathrm{~mm}$. face of head with uniform scattering of dark chromatophores, densest on upper half of sides. Some concentration of dark pigment also immediately anterior to anterior nasal barbel. Cranial fontanels visible in white, due to concentration of adipose tissue. Barbels lacking dark pigment except for faint fields of dark chromatophores at base of nasal and, sometimes, maxillary barbel. Opercular and interopercular odontodes darkly pigmented at their distal portions, with their protruding portions clearly visible against pale background integument (Figs. 1, 3). Fins white. Ventral part of body and head lacking dark integumentary pigment (Fig. 3).

Pigmentation in life. Pinkish on dorsal portion of body and lateral portion of head, showing an iridescent aspect. Cranial fontanel white. White coloration on lateral and ventral portions of body, due to concentration of adipose tissue. Eyes black (Fig. 5).

Etymology. The name spinosum is Latin for prickly, spiny, in allusion to the presence of opercular odontodes in this species, unique within the Copionodontinae.

Ecological data. The type locality is a quartzitic cave situated within the limits of the Chapada Diamantina National Park, in the Serra do Sincorá, one of the main components of the Chapada Diamantina, inside the limits of the Chapada Diamantina National Park. The local terrain is composed of arenites, siltites, argilites and conglomerates. Caves in this area are formed by the erosion of soft rock components by rainwater penetrating through surface cracks and leaving spaces delimited by the harder components. The water depth in the creek where the catfish live varies mostly between 10 and 50 $\mathrm{cm}$, with moderate current and some spotty accummulation of plant debris where fish are found foraging. Physico-chemico water variables in January 2007 were $\mathrm{pH} 4.1$; temperature $23.0^{\circ} \mathrm{C}$; conductivity $0.012 \mu \mathrm{S} / \mathrm{cm}$; dissolved oxygen $6.3 \mathrm{mg} / \mathrm{l}$.

Table 1. Morphometric data of holotype $(\mathrm{H})$ and paratypes of Glaphyropoma spinosum from Gruna dos Torras, Bahia State, northeastern Brazil ( $\mathrm{n}=5$, including holotype). $\mathrm{SD}$, standard deviation.

\begin{tabular}{lccc}
\hline & $\mathrm{H}$ & Paratypes & Mean \pm SD \\
\hline Standard length $(\mathrm{mm})$ & 58.2 & $34.9-45.6$ & $38.8 \pm 5.9$ \\
Total length & Percent of standard length & \\
Body depth & 114.1 & $116.4-117.3$ & $116.8 \pm 0.5$ \\
Predorsal length & 17.2 & $13.6-14.3$ & $13.9 \pm 0.3$ \\
Preanal length & 51.0 & $51.1-52.0$ & $51.5 \pm 0.5$ \\
Prepelvic length & 64.4 & $62.5-66.2$ & $64.4 \pm 1.9$ \\
Caudal peduncle length & 48.3 & $48.3-50.4$ & $49.5 \pm 1.1$ \\
Caudal peduncle depth & 13.1 & $10.7-15.2$ & $12.7 \pm 2.3$ \\
Dorsal-fin length & 9.5 & $8.3-10.0$ & $9.0 \pm 0.9$ \\
Anal-fin length & 12.5 & $12.2-15.2$ & $13.4 \pm 1.6$ \\
Head length & 14.4 & $16.7-20.3$ & $18.5 \pm 1.8$ \\
& 21.1 & $20.6-24.1$ & $22.5 \pm 1.7$ \\
Head width & 115.4 & $97.6-116.0$ & $106.2 \pm 9.2$ \\
Head depth & 58.5 & $51.2-59.6$ & $54.0 \pm 4.8$ \\
Snout length & 46.3 & $42.9-53.2$ & $48.7 \pm 5.3$ \\
Mouth width & 52.0 & $46.3-55.3$ & $50.6 \pm 4.5$ \\
Orbital diameter & 6.1 & $6.0-12.2$ & $8.9 \pm 3.1$ \\
Interorbital width & 39.0 & $39.0-41.5$ & $39.9 \pm 1.4$ \\
Interopercular patch of odontodes & 41.5 & $45.2-51.2$ & $47.4 \pm 3.3$ \\
\hline
\end{tabular}


Preliminary population data based on visual censuses were obtained in January and July, 2007, corresponding respectively to the rainy and dry seasons in the area. In a $150 \mathrm{~m}$ of long stream reach and $1 \mathrm{~m}$ of width (in average), 61 individuals were visually counted in January and 59 in July of 2007, and respectively population densities of 0.41 ind.m-2 (Jan 2007) and 0.39 ind.m-2 (Jul 2007), indicating little if any seasonal oscillations in population size. Most individuals were concentrated in quiet isolated pools (Fig. 6). The subterranean course of the creek extends for at least another 2,000 meters downstream, where, apparently the population is distributed (A. Auler \& L. Zogbi, pers. com.). Most of the caves in the upper sector of Chapada Diamantina were heavily impacted by diamond mining in the past, an activity which extended to the early 1990's and, in a residual clandestine fashion, continues to the present. This impact is visible in the blocks of rocks and remains of the miners inside the caves (lamps, bottles).

Additional copionodontine specimens found inside the cave may represent two other species that co-occur with G. spinosum. One of them is clearly related to Copionodon orthiocarinatus, and the other possible to $C$. pecten. In both cases the individuals found in the cave are troglomorphic, with a visible reduction of dark pigmentation, in some specimens, also of eyes in some specimens. A few individuals seem to be intermediates of Glaphyropoma and Copionodon catfish. Proper resolution of the taxonomic significance of these forms will require more detailed studies. The sympatric ocurrence of three copionodontine species has been recorded in the type locality of G. rodriguesi, C. pecten and C. orthiocarinatus, therefore it is not unexpected for this to also occur in the cave.

\section{Taxonomic discussion}

The new species here reported is clearly a member of the Copionodontinae. Among the seven synapomorphies previ-

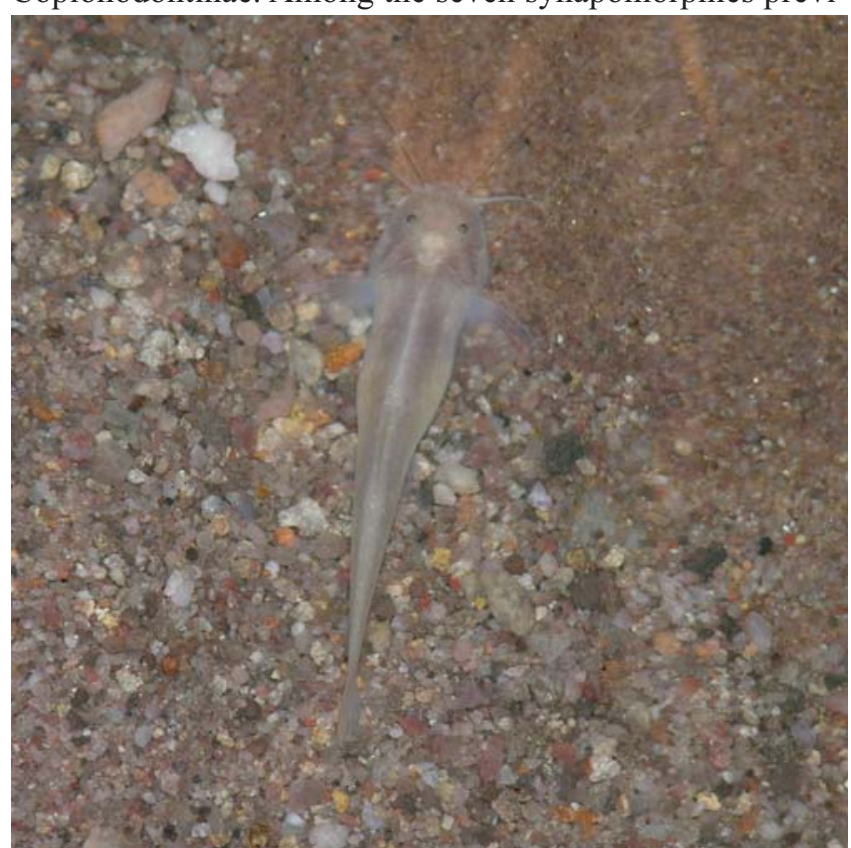

Fig. 5. Detail of Glaphyropoma spinosum in its natural habitat. Photo: M. E. Bichuette. ously recognized for the subfamily (de Pinna, 1992), only one, the large articular process of the scaphium, could not be confirmed in G. spinosum because of the limited material available of the species. Direct evidence for the inclusion of the new species in the genus Glaphyropoma is limited to the original character proposed as autapomorphic for G. rodriguesi in de Pinna (1992), namely the slender shape of the first hypobranchial. The same character state is present in G. spinosum (Fig. 6). Other comparative data originally used to diagnose Glaphyropoma, however, also support the inclusion of the new species therein, as opposed to Copionodon. Such characters include the lack of a free orbital rim, the small eye, the non-bilobed caudal fin, the non-overlapping dentary and premaxillary teeth, the dentary dentition extending to the base of the coronoid process, the lower lip not interrupted by a median ridge, the long barbels, the broad head (wider than long in adult specimens), and the deepest portion of the adipose fin located at its posterior half. Some of these character states are obviously plesiomorphic when compared to those in Copionodon, and others are of uncertain polarity. Such evidence, however, in combination with the one synapomorphy mentioned above, support the inclusion of the new species in Glaphyropoma.

The most interesting feature of Glaphyropoma spinosum is the presence of opercular odontodes, a trait previously unknown in copionodontines. Trichomycterids in general have opercular odontodes. Some instances of their absence in the family are obvious results of reversals, such as in some glanapterygines of the genera Pygidianops Myers and Typhlobelus Myers. Copionodontines were the only case where the lack of odontodes in trichomycterids was phylogenetically ambiguous. Because of their basal position in the family, combined with the lack of opercular odontodes in the Nematogenyidae, sister group to the Trichomycteridae, it was hypothesized that the lack of odontodes in copionodontines was primitive (Pinna, 1992). The discovery of G. spinosum

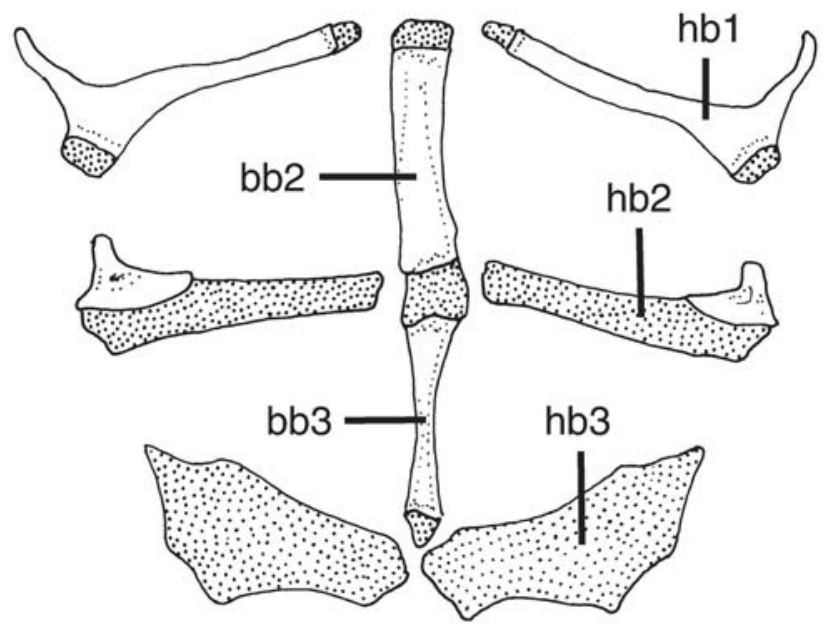

Fig. 6. Ventral elements of branchial arches in Glaphyropoma spinosum, new species. Dorsal view. Last basibranchial not represented; bb2-3, basibranchials 2 to 3; hb1-3, hypobranchials 1 to 3 . Scale bar $=1 \mathrm{~mm}$. 
refutes that interpretation. The presence of opercular odontodes in a member of Copionodontinae makes it highly unlikely that their absence in other species of the subfamily is primitive for trichomycterids. The strength of the evidence relies not only on the mere presence of opercular odontodes, but also on the associated morphology of the opercle in G. spinosum. As in most trichomycterids, the opercular odontodes of G. spinosum are clustered in the dorsoposterior extremity of the opercle, forming a projected bony platform (Fig. 4). Such condition comprises a set of apomorphic modification which are typical of the trichomycterid opercular apparatus.

This interpretation results in the revaluation of lower trichomycterid relationships. In the original paper describing copionodontines de Pinna (1992) offered evidence for the placement of that clade as sister taxon to all other trichomycterids, with the Trichogeninae as the next sister group. While the evidence for a clade composed of non-copionodontine, nontrichogenine trichomycterids was remarkably strong, the support for the Trichogeninae as sister group to that clade was limited to a single character. Later, a number of putative synapomorphies were identified to occur exclusively in the Copionodontinae and Trichogeninae (de Pinna, 1998). At that time, a change in hypotheses was deemed premature and the relationships among the three lineages were considered as unresolved. Such reticence seems no longer reasonable, and the sheer number of derived characters shared exclusively by copionodonines and trichogenines (listed in de Pinna, 1998) makes it quite obvious that the most parsimonious solution is to consider the two taxa as sister groups. The two-subfamily clade is, then, considered as sister group to remaining trichomycterids as per the evidence previously presented in de Pinna (1992). The relevance of this change in hypotheses for the present discussion is that Trichogenes longipinnis, sole species of the Trichogeninae, has opercular odontodes, though in a form highly modified (e.g., divided into two patches) from the one normally seen in other trichomycterids.

In summary, the discovery of Glaphyropoma spinosum plus the placement of the Trichogeninae and Copionodontinae as sister groups support the hypothesis that the absence of opercular odontodes within Copionodoninae is secondary. The opercular armature is a key element in the tremendous lifehistory radiation of Trichomycteridae, which comprise lineages ranging from psammophilic to parasitic. Having a clearer picture of the evolution of the opercular armature in the deep portions of trichomycterid phylogeny will facilitate an understanding of its evolution in more distal clades.

Indeed, the species is the first in the subfamily to display troglomorphic characteristics, such as the reduction of eyes and of dark integumentary pigmentation indicating a troglobitic (exclusively subterranean) condition.

\section{Speleological comments}

The existence of well developed subterranean habitats, with associated ecosystems, in quartzitic was recognized quite recently. Due to the low solubility of siliceous rocks, when compared to the carbonates, and the rarity of silicate caves in temperate regions, where karst researchers used to live and study, lead to the notion that silicate lithologies would represent a disruption of the subterranean environment. With the development of tropical karstology, important quartzitic subterranean systems were identified in South America (Venezuela and Brazil), Africa and Australia (Martini, 2004).

Therefore, the presence of troglobites in silicate caves, especially in quartzites (the most soluble among siliceous rocks), is not unexpected. In fact, troglobitic invertebrates have been found in Lapão Cave, a quartzite cave situated in another area within Chapada Diamantina, as is the case with the first Brazilian troglobitic scorpion (Troglorhopalurus translucidus; Lourenço et al., 2005) and ctenid spider (R. Baptista, pers. comm.).

Likewise, the presence of highly troglomorphic Rhamdiopsis catfish (Heptapteridae) in a wide limestone area in the Chapada Diamantina, intersected by a quartzite outcrop crossing through the Lençois area (where Lapão Cave is located), indicates that such outcrop is not an effective barrier for subterranean dispersion of fish. Nevertheless, no fish species has been previously found with a well established population living in the quartzite area. Glaphyropoma spinosum represents the first record of a Brazilian troglobitic fish in a silicate karst.

\section{Acknowledgments}

We are especially grateful to Raimundo Cruz dos Santos ("Xiquinho") from Povoado de Igatu, for the first information on Glaphyropoma spinosum and for his valuable help during fieldwork. Research funding is provided by FAPESP (Fundação de Amparo à Pesquisa do Estado de São Paulo, process \# 2003/00794-5), All Catfish Species Inventory Project (NSF DEB-0315963) and CNPq (Conselho Nacional de Desenvolvimento Científico e Tecnológico). We also thank Eduardo Baena for the photographs of the holotype, Flávio Dias Passos, Tiago Luís Castro Scatolini and Richard Borowsky for assistance in fieldwork.

\section{Literature Cited}

Campanario, C. M. \& M. C. C. de Pinna. 2000. A new species of the primitive trichomycterid subfamily Copionodontinae from norheastern Brazil (Teleostei: Trichomycteridae). Ichthyological Explorations of Freshwaters, 11: 369-375.

Lourenço, W. R., R. L. C. Baptista \& A. P. L. Giupponi. 2004. Troglobitic scorpions: a new genus and species from Brazil. Comptes Rendus Biologies, 327: 1151-1156.

Martini, J. 2004. Silicate karst. Pp. 649-653. In: Gunn, J. (ed.). Encyclopedia of Caves and Karst Science. Fitzroy Dearborn, New York \& London, 902 p.

de Pinna, M. C. C. 1992. A new subfamily of Trichomycteridae (Teleostei, Siluriformes), lower loricarioid relationships and a discussion on the impact of additional taxa for phylogenetic analysis. Zoological Journal of the Linnean Society, 106: 175-229.

de Pinna, M. C. C. 1998. Phylogenetic relationships of neotropical Siluriformes (Teleostei: Ostariophysi): historical overview and synthesis of hypotheses. Pp. 279-330. In: L. R. Malabarba, R. E. Reis, R. P. Vari, Z. M. Lucena and C.A.S. Lucena (Eds.). Phylogeny and Classification of Neotropical Fishes. Porto Alegre, Edipucrs, 603p.

Taylor, W. R. \& G. C. Van Dyke. 1985. Revised procedures for staining and clearing small fishes and other vertebrates for bone and cartilage study. Cybium, 9(2):107-19.

Accepted August, 2008

Published September 30, 2008 